\title{
Heritability of Cognitive Functions in Families of Successful Cognitive Aging Probands from the Central Valley of Costa Rica
}

\author{
Tiffany A. Greenwood ${ }^{a}$, Michal S. Beeri ${ }^{b, c, d}$, James Schmeidler ${ }^{b}$, Daniel Valerio ${ }^{e, f}$, Henriette \\ Raventós $^{f, g}$, Lara Mora-Villalobos ${ }^{f}$, Karla Camacho $^{f}$, José R. Carrión-Baralt ${ }^{\mathrm{h}}$, Gary Angelo ${ }^{\mathrm{b}}$, \\ Laura Almasy', Mary Sano ${ }^{\mathrm{b}, \mathrm{j}}$, and Jeremy M. Silverman ${ }^{\mathrm{b}, \mathrm{d}, \mathrm{j},{ }^{,},}$ \\ aDepartment of Psychiatry, University of California San Diego, La Jolla, CA, USA \\ bDepartment of Psychiatry, Mount Sinai School of Medicine, New York, NY, USA \\ 'Geriatric Research, Education and Clinical Center, James J. Peters Veterans Affairs Medical \\ Center, Bronx, New York, NY, USA \\ dFriedman Brain Institute, Mount Sinai School of Medicine, New York, NY, USA \\ eHospital Nacional de Geriatría y Gerontología de Costa Rica, San José, Costa Rica \\ fCentro de Investigación en Biología Molecular y Celular, Universidad de Costa Rica, San José, \\ Costa Rica \\ gEscuela de Biología, Universidad de Costa Rica, San José, Costa Rica \\ hGerontology Program, Department of Human Development, Graduate School of Public Health, \\ University of Puerto Rico Medical Sciences Campus, Rio Piedras, Puerto Rico \\ iSouthwestern Foundation for Biomedical Research, San Antonio, Texas, USA \\ jResearch and Development Service, James J. Peters Veterans Affairs Medical Center, Bronx, \\ New York, NY, USA
}

\section{Abstract}

We sought to identify cognitive phenotypes for family/genetic studies of successful cognitive aging (SCA; maintaining intact cognitive functioning while living to late old age).We administered a battery of neuropsychological tests to nondemented nonagenarians $(n=65$; mean age $=93.4 \pm 3.0)$ and their offspring $(n=188$; mean age $=66.4 \pm 5.0)$ from the Central Valley of Costa Rica. After covarying for age, gender, and years of education, as necessary, heritability was calculated for cognitive functions at three pre-defined levels of complexity: specific neuropsychological functions (e.g., delayed recall, sequencing), three higher level cognitive domains (memory, executive functions, attention), and an overall neuropsychological summary. The highest heritability was for delayed recall $\left(h^{2}=0.74, s e=0.14, p<0.0001\right)$ but significant heritabilities involving memory were also observed for immediate recall $\left(h^{2}=0.50\right)$, memory as a cognitive domain $\left(h^{2}=0.53\right)$, and the overall neuropsychological summary $\left(h^{2}=0.42\right)$. Heritabilities for sequencing $\left(h^{2}=0.42\right)$, fluency $\left(h^{2}=0.39\right)$, abstraction $\left(h^{2}=0.36\right)$, and the executive functions cognitive domain $\left(h^{2}=0.35\right)$ were also significant. In contrast, the attention domain and memory recognition were not significantly heritable in these families. Among the heritable specific cognitive functions, a strong pleiotropic effect (i.e., evidence that these may be

(C) 2011 - IOS Press and the authors. All rights reserved

"Correspondence to: Jeremy M. Silverman, Ph.D., Department of Psychiatry, Box 1230, Mount Sinai School of Medicine, One Gustave L. Levy Place, NY 10029, USA. Tel.: +212 659 8822; Fax: +212 659 5626; jeremy.silverman @ mssm.edu.

Authors' disclosures available online (http://www.jalz.com/disclosures/view.php?id=968). 
influenced by the same gene or set of genes) for delayed and immediate recall was identified (bivariate statistic $=0.934, p<0.0001$ ) and more modest but significant effects were found for four additional bivariate relationships. The results support the heritability of good cognitive function in old age and the utilization of several levels of phenotypes, and they suggest that several measures involving memory may be especially useful for family/genetic studies of SCA.

\section{Keywords}

Family studies; hispanic population; neuropsychological phenotype; oldest-old; successful cognitive aging

\section{INTRODUCTION}

Several genes have been identified with variants that either cause or increase the risk for Alzheimer's disease (AD) [1], and there has been recent notable progress in the search for others [2-4]. The genetics of successful cognitive aging (SCA; maintaining intact cognitive functioning while living to late old age) has been studied much less. Genes with variants that protect against late life cognitive impairment may overlap to some extent with genes with alleles that increase risk. At present, the apolipoprotein E (APOE) gene provides the only strongly confirmed example of this [5, 6], where the APOE- 44 allele increases risk and the APOE- 22 allele protects against dementia. Alternatively, there may be genes associated with late life cognition that do not possess minor alleles increasing both risk and protection. Genes with infrequent minor protective allele(s)would not likely be identified in current research focused on dementia if there were not also an allele associated with dementia, such as APOE-ع4 [7]. In view of the multidimensionality of both cognitive function and longevity, simply living to a very late age without dementia may be too genetically complex to meaningfully empower such a search [7-10]. Delineating phenotypes for SCA could facilitate the search for relevant genes that hold the potential to reveal much about the physiology of resilient late-life cognitive function; such knowledge would be harder to glean from studies of dementia alone.

A large, consistent literature, based primarily on studies of twins and families rather than molecular genetics per se, already demonstrates the important influence of genetic factors on normal cognitive function in early life [11]. While not so well established, twin study evidence suggests that genetic factors are important for late life cognitive function too [9, 12], and not subsumed simply by those directly associated with risk of dementia [13]. Also, family studies of SCA have reported that the first degree relatives of SCA probands have a reduced risk for dementia $[7,14,15]$, consistent with the presence of familial/genetic underpinnings for SCA.

If the genetic basis of SCA involves multiple genes [8-10], identifying cognitive phenotypes associated with SCA will facilitate genetic studies. Such phenotypes may pertain to different levels of cognitive complexity, reflecting genetic factors affecting specific or broader cognitive functions. Results from genetic epidemiological studies suggest that some genes may be "generalist" in their cognitive effects, i.e., they may have broad effects on cognitive function $[11,16]$. Such genes might, for example, influence a core physiological (e.g., synaptic plasticity), physical (e.g., neural density), or other process that, in turn, may lead to a broad or cascading effect on a range of cognitive functions [16]. Under a generalist gene hypothesis, such genes would be best detectable by characterizing an overall measure of cognitive functioning in individuals, or by having associated deficits in a wide variety of cognitive functions rather than a deficit in one specific area. This approach argues for determining the heritability of a summarizing measure of neuropsychological function [16]. 
Alternatively, such genes may influence a specific cognitive function or only a set of closely related functions. Twin and family data suggest that specific components of memory, such as delayed recall, have a high heritability, while other cognitive functions may have a much lower heritability, depending on the sample characteristics $[9,10,17,18]$. Recently, molecular genetic studies have reported on polymorphisms that have effects on specific cognitive functions. For example, common variants of the Kibra (WWC1) and the Cholesteryl Ester Transfer Protein (CETP) genes have been found to be associated with episodic memory and not with other cognitive functions [19-23].

To evaluate the heritability of cognitive function in SCA at several different levels of cognitive complexity, we examined SCA probands and their offspring ascertained in the Central Valley of Costa Rica (CVCR). The CVCR population has many features that make it attractive for genetic studies. While the CVCR population used for these analyses is considered an admixed population, this admixture occurred during the time of the colonialization of Costa Rica in the sixteenth century [24]. Since that time, the people of the Central Valley region (two thirds of Costa Rica's $3.5+$ million people live in the CVCR) have remained demographically isolated, with reduced genetic heterogeneity, observed especially among the very elderly of the region and advantageous for genetic studies. A recent genetic study of 426 unrelated CVCR individuals with a familial history of mental disorder provided no evidence for population substructure [25]. Other advantageous features of the CVCR population include a high level of cultural homogeneity which helps to limit environmental disparities, close knit families, and a small geographic size, typically making sibship members readily accessible for study [26, 27].

\section{MATERIALS AND METHODS}

All participants were recruited in accordance with the principles of the Helsinki Declaration and approval of the Institutional Review Boards of the University of Costa Rica and Mount Sinai Medical Center. All individuals signed informed consent prior to their participation.

\section{SCA probands}

SCA probands with at least one living, available offspring were ascertained through referrals to the study geriatric physician (DV) from a network of cooperating physicians associated with the Costa Rican Association of Geriatricians. Probands and their spouses were required to be native to the CVCR. Eligible probands were required to be at least 90 years of age, as verified by the cédula, the national identity card that every Costa Rican citizen possesses and which includes a picture ID and the individual's date and place of birth. The age 90 threshold was chosen because prior studies indicate the relatives of nondemented $90+$ year olds maintain intact cognitive function better even than relatives of nondemented elderly who are still in their late 80s [7].

Probands received a clinical dementia evaluation using the Clinical Dementia Rating scale (CDR) [28] and the Mini-Mental State Examination [29] and a medical exam by a geriatrician. In the CDR, clinical information is collected from both an informant and the subject. The subject's memory, judgment, orientation, home and hobbies, community affairs, and personal care are assessed. Probands were required to have a CDR score of zero, indicating no dementia or recent decline in cognition or functioning. Additionally, the physician (DV) with expertise in dementia assessed all probands and ensured their cognitive normal status. We deliberately did not include neuropsychological testing performance as a criterion for proband eligibility to avoid circularity in our study since the dependent variables—cognitive functions—under study were derived from these test scores. 


\section{Offspring of SCA probands}

We recruited the $60+$ year old offspring of SCA probands for this study. Contact with a given offspring was made through the proband. While the proband's intact cognitive status was a determinant for eligibility, this was not the case for the offspring; the presence of dementia, for example, was not an exclusion, although to date such cases have been absent in our sample.

\section{Neuropsychological assessment}

The neuropsychological test battery included Spanish translations of the Uniform Data Set (UDS) battery and supplemental tests used to characterize cognitive functions. Validity of this battery is supported by our overall similar results, after taking into account the difference in years of education, for the Spanish and English versions of the test battery in respective samples of nonagenarians from Puerto Rico and New York [30]. Based on earlier factor analyses of neuropsychological batteries, we have conducted in elderly samples [3032] as well as factor analyses from other researchers [33, 34], we defined phenotypes at three levels of cognitive complexity. The lowest level focused on specific neuropsychological functions (e.g., delayed recall, sequencing). The middle level focused on three key cognitive domains: memory, executive functions, and attention. The highest level was an overall summary score of cognitive functioning. The tests were administered at the homes of the subjects by team psychologists $(\mathrm{LV}, \mathrm{KC})$ who were trained and certified by JCB and who, along with JMS, MSB, and MS, provided ongoing supervision. The specific functions and the associated tests administered were:

\section{Memory domain}

i. Immediate Recall. Word List Memory [35]: a free recall memory test that assesses learning ability for new verbal information. Three trials of a 10-item word list are presented with varying orders on each trial. Immediately following each trial, the subject is asked to recall as many as possible. The sum of the correct words over the three trials is the measure. Logical Memory: this is a subtest of the Wechsler Memory Scale-III [36] in which the tester reads a story aloud and subjects are asked to immediately recall it. The number of 25 specific details mentioned is the score. This story is also used to measure delayed recall and recognition.

ii. Delayed Recall. Word List: after a 15 minute delay (filled with other tests in the battery), subjects are asked to recall the 10 words of the Word List Memory test. Logical Memory: after a 25-30 minute delay, subjects are asked to recall the story from the Logical Memory test.

iii. Recognition. Word List: The 10 words in the Word List Memory test are presented along with 10 distracter words. The score equals the number of correctly recognized (Rec-yes) plus the number of distracter words correctly identified (Recno). Since this had a substantially skewed distribution, a logarithmic transformation was applied, $-\log$ (21-score), which yielded an approximately normal distribution.

\section{Executive functions domain}

i. Sequencing. Trail Making Tests: these tests measure timed attention, mental flexibility, and sequencing. In Part $A$ the subject is asked to connect randomly positioned numbers in sequence with a pencil. In Part $B$ subjects are asked to connect consecutive numbers and letters in alternating order [37]. The score used for each test is the time (seconds) to completion.

ii. Abstraction. Similarities: this is a subtest from the Wechsler Adult Intelligence Scale-Revised [38] measuring abstract thinking by asking the subject to state how 
pairs of words (e.g., egg/seed) are alike. The number of correctly answered pairs is the single measure from this test.

iii. Fluency. Controlled Oral Word Association Test: in three one-minute trials, this test of phonemic fluency assesses the ability to name as many words as possible with three different letters. The English version uses F, A, and S [39] but, as the letters "S" and " $Z$ " always sound like an "S" in Spanish, this letter has been changed to "N". The single measure is the sum of words in all three trials. Category Fluency: Subjects are asked to generate exemplars of animals, foods, and clothing; 60 seconds are allowed for each category. The score is the sum of the exemplars of the different categories [40].

\section{Attention domain}

i. Visual/Spatial Attention. Target Cancellation Tests [41]: these tests assess vigilance and speeded attention, requiring an organized, planned search. Two forms are used here, the Letters test requires the subject to identify the letters 'TMX' in an array of letter triads; the Shapes test requires the subject to identify diamonds among other geometric figures. Target stimuli are interspersed with distracter items on a sheet of 8.5-by-11 paper in a generally random format. The numbers of targets identified in two minutes on each task are the two measures.

Figure 1 shows the three cognitive levels of phenotypes examined and the associated tests. These phenotypes were chosen to facilitate replication in independent samples. Each specific neuropsychological function in the lowest level was estimated by the sums of zscores of sets of one or more neuropsychological measures. For example, z score transformations were calculated for both the word list test and the logical memory test and the two scores were then summed to derive a score for the neuropsychological function, immediate recall. For the middle level, the memory and executive functions were each estimated by a sum of z-scores of a set of three neuropsychological functions from the level below. For the cognitive domain of attention, the two versions of the Target Cancellation Task, letters and shapes, were used, but they were not considered sufficiently different to be treated as distinct neuropsychological functions at the lowest level. Moreover, the distribution of the summed z-scores of these two measures was highly kurtotic. The sum of z-scores of these two measures was log-transformed, yielding an estimate of attention that was approximately normally distributed. Finally, the overall neuropsychological summary was the phenotype estimated by the sum of z-scores of the three cognitive domains.

\section{Statistical analysis}

Heritability $\left(h_{\mathrm{r}}^{2}\right)$ estimates were obtained for each cognitive function phenotype using the variance component methodology implemented in the SOLAR v.2.1.2 linkage analysis package [42]. Although the variance component method is quite robust to violations of multivariate normality within pedigrees $[43,44]$, the distribution of values for each phenotype was analyzed to assess large departures. All phenotypes were approximately normally distributed with no significant outliers identified. Since controlling for the effects of a known covariate is important for obtaining an accurate estimate of heritability, three factors (age, gender, and years of education) likely to affect these phenotypes were screened for significance as covariates using SOLAR. Although the APOE genotype was determined for most of the subjects $(n=246)$, the allele frequencies for $\varepsilon 4$ and $\varepsilon 2$ were sufficiently low (6.8\% and $2 \%$, respectively) that APOE was not screened as a potential covariate because it would be unlikely to account sufficient variation in the entire sample. Only those factors that showed significant $(p<0.05)$ associations were retained in the heritability analysis of that phenotype. For pairs of domains and pairs of phenotypes with significant heritability, bivariate genetic $\left(\rho_{G}\right)$ and environmental $\left(\rho_{E}\right)$ correlations were also computed using 
SOLAR $[45,46]$. The genetic correlation between two phenotypes is the component of the overall correlation that is due to pleiotropy (i.e., single genetic effects influencing multiple phenotypes), which is obtained from kinship information in the pedigree. The environmental correlation is the component of the correlation due to environmental factors that influence both measures, which is obtained from the individual-specific error.

\section{RESULTS}

The upper portion of Table 1 presents the demographic characteristics of the SCA probands, their offspring, and the combined group of relatives. The lower portion of Table I presents the scores for each of the cognitive phenotypes. To reflect the organization of the phenotypes, as shown in Fig. 1, we have indented the three cognitive domains in Table I, and further indented the specific neuropsychological phenotypes investigated.

We assessed 84 eligible enrolled SCA probands and 188 of their offspring. Of these, 19 probands had incomplete neuropsychological test data, so they could not be included in the heritability analysis, but their 53 offspring were included, for a total of 253 family members. In a subsidiary analysis, we limited the heritability analysis to only those families that included a proband without missing data and the results were very similar (data not shown).

Heritability results and their significance levels for each phenotype are shown in Table 2. The overall neuropsychological summary and two of the three cognitive domains (memory and executive functions) were found to be significantly heritable, but not the attention domain. Within the memory domain, delayed and immediate recall were significantly heritable, but not recognition. The three associated specific neuropsychological functions associated with executive functions were also significantly heritable.

The last three columns of Table II present the significance levels of the three potential covariates (employed in the heritability analysis only if $p<0.05$ ). For every phenotype, more years of education was found to be highly significantly associated with better neuropsychological functions, domains, and the overall summary score. Also, later age was significantly associated with better executive functions performance and the overall neuropsychological summary score, but was not associated with the memory phenotypes or attention. Gender was a significant covariate only for the memory domain and the immediate and delayed recall phenotypes, where the performance scores for women were better than for men (data not shown).

In a subsidiary analysis, we excluded probands and calculated heritability among only the offspring. These results, shown in Table 3, were generally similar to those observed with the SCA probands included.

The significant bivariate correlations, shown in Table $4 \mathrm{a} \& \mathrm{~b}$, are estimates of the strength of the components of the observed correlations between each pair of heritable phenotypes that can be attributable to genetic $\left(\rho_{\mathrm{G}}\right.$; below the diagonal) and environmental $\left(\rho_{\mathrm{E}}\right.$; above the diagonal) factors. A larger $\rho_{G}$ is generally indicative of increased evidence for shared genes (pleiotropy).We also present significance corrected for multiple testing using the Bonferroni method, which may be unduly conservative due to the correlations among many of the neuropsychological functions. A very strong genetic correlation was observed between immediate and delayed recall. Immediate recall was also correlated with sequencing and abstraction, as were the latter two phenotypes with each other. There was also a significant correlation between delayed recall and abstraction. We additionally examined environmental correlations and found that fluency, which was not genetically correlated with any other phenotype, was correlated with all the other specific neuropsychological functions in contrast to all the other separate pair-wise combinations of phenotypes. No significant 
genetic correlations were observed between the two heritable cognitive domains, but a significant environmental correlation between the memory and executive domains was observed.

\section{DISCUSSION}

Genetic factors, even beyond their association with dementias such as AD [13], likely underlie the variability in cognitive function across individuals as they move into late life [47]. SCA, in particular, has been repeatedly found to be a familial characteristic and probably has genetic underpinnings $[7,14,15]$. Delineation of heritable SCA cognitive phenotypes may be useful for the identification of its genetic determinants. In a CVCR ascertained sample of SCA probands and their offspring, we considered three levels of phenotypic complexity. In support of our multi-level approach to cognitive phenotypes in late life, within each of the three levels of phenotypes there were significant heritabilities. Nonetheless, we note that the strongest heritabilities were mostly found at the most specific level of function and these were reduced higher levels. Although we cannot rule out the possibility that shared familial environmental influences have affected these heritability calculations, our results suggest that most of cognitive phenotypes examined have good potential to be useful in the search for genes associated with SCA.

Two specific functions related to memory, delayed recall and immediate recall, had the highest heritabities and, among the three cognitive domains, memory was highest, suggesting that certain memory-related phenotypes may be particularly valuable in the search for genetic determinants associated with SCA. On the other hand, recognition, another cognitive function related to memory, and the attention domain were not found to be heritable in this sample and hence are probably less useful for genetic studies.

The bivariate analyses we conducted that assessed the genetic and environmental associations between pairs of phenotypes within the same level of phenotypic complexity indicated several significant environmental and genetic inter-correlations, especially the genetic inter-correlation between delayed and immediate recall $\left(\rho_{G}=0.96\right)$. The genetic correlations offer opportunities to explore the potential common underlying genetic and neurobiologic substrates of these phenotypic measures. These will be possible as the sample grows and genetic data become available. The presence of significant inter-domain genetic associations as well as intra-domain associations is consistent with the possibility of pleiotropic effects, but lack of significance for many pair-wise associations argues against exclusively generalist genes.

That delayed recall showed the highest heritability is consistent with other studies that assessed heritability in aged twin and family samples [48]. In particular, our results showed some similarities to a study of families with AD probands ascertained in the Dominican Republic and Puerto Rico where the heritability for delayed recall in their full family sample was $60 \%$, whereas heritability for recognition, while significant, was less high (41\%) [17]. In our study, heritability for delayed recall was even somewhat higher while recognition was low and not significant when the probands were included and showed a modest significant heritability when offspring alone were included. The reason for the discrepancy in the results with recognition may depend on our use of a logarithmic transformation. In addition, two distinguishing characteristics of our sample was that no subjects had dementia and all the subjects either were SCA probands - a relatively rare, desirable condition associated with familial/genetic protection of cognitive functions [7, 14, 15]—or their offspring.

Beyond its strong association with $\mathrm{AD}$ and other dementias, investigations of the APOE- $\varepsilon 4$ allele in cognitively healthy elderly have collectively found modest effects on overall 
neuropsychological functioning and on memory, but smaller or no effects on other specific cognitive functions [49]. Although age-associated memory impairments may indicate a degenerative process, a decremental impairment in attention or executive function may be a normal characteristic of aging [50]. Thus, the stronger impact of the APOE $\varepsilon 4$ allele on memory over other cognitive domains may speak to a stronger relationship with dementia risk than an influence on normal cognitive function [51]. Since as discussed above, it is unlikely that the relatively low variation of APOE alleles had substantial effect on the documented heritabilities, the findings support contributions from genes other than APOE on memory and other cognitive functions. Such genes need not be associated with AD pathophysiology per se, but may also be associated with maintaining good cognitive functioning even in the face of $\mathrm{AD}$-related processes such as plaque formation. For example, the cognitive reserve theory relates such maintenance to a high level of prior cognitive performance $[52,53]$. Protective genes may help explain reports of high levels of AD neuropathology found in brains of some very long-lived cognitively intact individuals [53$55]$.

The covariates were incorporated in the heritability analyses to remove the confounding effects of demographic variables on cognition. The absence of a strong covariate effect of age is surprising in view of the well established association of age with memory in samples from general populations [56]. A recent study from our group developed norms for very elderly nondemented subjects from the New York City area on 14 neuropsychological tests on which most tests in this study were based. For the tests of memory, the pattern of significances for age was the similar to that of the present study, except that one of two recognition tests was significant. Also, in a sample of nondemented nonagenarians Puerto Ricans, none of the neuropsychological tests were significantly associated with age or gender, but most were associated with education [30]. Although the age ranges were restricted in those previous studies to cognitively intact $85+$ and $90+$ year olds, respectively, including only SCA probands and their offspring in the present study may have reduced the association of age with memory by reducing dementia-associated effects.

There are methodological considerations and limitations in this study that require attention. First, since the sample was restricted to very elderly nondemented probands and their offspring, these heritabilities may not be characteristic of the general population. Indeed, some twin studies reflecting the more general population of nondemented elderly have found somewhat different patterns of heritability [9]. Second, our neuropsychological battery included three important cognitive domains, but the number of phenotypes in each domain (especially for attention) and the number of tests in phenotypes were limited. Third, the variation in APOE genotypes was not sufficiently large to distinguish its heritability from other sources with this sample size. Finally, we note that we did not have systematic information on medical co-morbidities and treatments and thus could not include these as potential covariates that might have affected cognitive function.

Our results suggest that cognitive phenotypes at several levels, focusing especially on memory (overall neuropsychological summary, memory, and delayed recall) have substantial heritability that may prove useful for identifying genes associated with SCA.

\section{Acknowledgments}

The authors are grateful for the support from the Alzheimer's Association, Project 4 in P01-AG02219; K01 AG023515; K01 AG025203; P50-AG05138; UL1RR029887 to Mount Sinai for the CTSA; the United States Department of Veterans Affairs; Berkman Charitable Trust. We are grateful for the assistance of Tatiana Salazar and Patricia Bolaños, especially with respect to database management and quality assurance. In addition, we thank the family members who participated in this project and the Costa Rica Association of Geriatricians for their generous help. 


\section{REFERENCES}

1. Bekris LM, Yu CE, Bird TD, Tsuang DW. Genetics of Alzheimer disease. J Geriatr Psychiatry Neurol. 2010; 23:213-227. [PubMed: 21045163]

2. Jun G, Naj AC, Beecham GW, Wang LS, Buros J, Gallins PJ, Buxbaum JD, Ertekin-Taner N, Fallin MD, Friedland R, Inzelberg R, Kramer P, Rogaeva E, St George-Hyslop P, Cantwell LB, Dombroski BA, Saykin AJ, Reiman EM, Bennett DA, Morris JC, Lunetta KL, Martin ER, Montine TJ, Goate AM, Blacker D, Tsuang DW, Beekly D, Cupples LA, Hakonarson H, Kukull W, Foroud TM, Haines J, Mayeux R, Farrer LA, Pericak-Vance MA, Schellenberg GD. Meta-analysis confirms CR1, CLU, and PICALM as alzheimer disease risk loci and reveals interactions with APOE genotypes. Arch Neurol. 2010; 67:1473-1484. [PubMed: 20697030]

3. Naj AC, Jun G, Beecham GW, Wang LS, Vardarajan BN, Buros J, Gallins PJ, Buxbaum JD, Jarvik GP, Crane PK, Larson EB, Bird TD, Boeve BF, Graff-Radford NR, De Jager PL, Evans D, Schneider JA, Carrasquillo MM, Ertekin-Taner N, Younkin SG, Cruchaga C, Kauwe JS, Nowotny P, Kramer P, Hardy J, Huentelman MJ, Myers AJ, Barmada MM, Demirci FY, Baldwin CT, Green RC, Rogaeva E, George-Hyslop PS, Arnold SE, Barber R, Beach T, Bigio EH, Bowen JD, Boxer A, Burke JR, Cairns NJ, Carlson CS, Carney RM, Carroll SL, Chui HC, Clark DG, Corneveaux J, Cotman CW, Cummings JL, DeCarli C, DeKosky ST, az-Arrastia R, Dick M, Dickson DW, Ellis WG, Faber KM, Fallon KB, Farlow MR, Ferris S, Frosch MP, Galasko DR, Ganguli M, Gearing M, Geschwind DH, Ghetti B, Gilbert JR, Gilman S, Giordani B, Glass JD, Growdon JH, Hamilton RL, Harrell LE, Head E, Honig LS, Hulette CM, Hyman BT, Jicha GA, Jin LW, Johnson N, Karlawish J, Karydas A, Kaye JA, Kim R, Koo EH, Kowall NW, Lah JJ, Levey AI, Lieberman AP, Lopez OL, Mack WJ, Marson DC, Martiniuk F, Mash DC, Masliah E, McCormick WC, McCurry SM, McDavid AN, McKee AC, Mesulam M, Miller BL, Miller CA, Miller JW, Parisi JE, Perl DP, Peskind E, Petersen RC, Poon WW, Quinn JF, Rajbhandary RA, Raskind M, Reisberg B, Ringman JM, Roberson ED, Rosenberg RN, Sano M, Schneider LS, Seeley W, Shelanski ML, Slifer MA, Smith CD, Sonnen JA, Spina S, Stern RA, Tanzi RE, Trojanowski JQ, Troncoso JC, Van DV, Vinters HV, Vonsattel JP, Weintraub S, Welsh-Bohmer KA, Williamson J, Woltjer RL, Cantwell LB, Dombroski BA, Beekly D, Lunetta KL, Martin ER, Kamboh MI, Saykin AJ, Reiman EM, Bennett DA, Morris JC, Montine TJ, Goate AM, Blacker D, Tsuang DW, Hakonarson H, Kukull WA, Foroud TM, Haines JL, Mayeux R, Pericak-Vance MA, Farrer LA, Schellenberg GD. Common variants at MS4A4/MS4A6E, CD2AP, CD33 and EPHA1 are associated with late-onset Alzheimer's disease. Nat Genet. 2011; 43:436-441. [PubMed: 21460841]

4. Hollingworth P, Harold D, Sims R, Gerrish A, Lambert JC, Carrasquillo MM, Abraham R, Hamshere ML, Pahwa JS, Moskvina V, Dowzell K, Jones N, Stretton A, Thomas C, Richards A, Ivanov D, Widdowson C, Chapman J, Lovestone S, Powell J, Proitsi P, Lupton MK, Brayne C, Rubinsztein DC, Gill M, Lawlor B, Lynch A, Brown KS, Passmore PA, Craig D, McGuinness B, Todd S, Holmes C, Mann D, Smith AD, Beaumont H, Warden D, Wilcock G, Love S, Kehoe PG, Hooper NM, Vardy ER, Hardy J, Mead S, Fox NC, Rossor M, Collinge J, Maier W, Jessen F, Ruther E, Schurmann B, Heun R, Kolsch H, van den BH, Heuser I, Kornhuber J, Wiltfang J, Dichgans M, Frolich L, Hampel H, Gallacher J, Hull M, Rujescu D, Giegling I, Goate AM, Kauwe JS, Cruchaga C, Nowotny P, Morris JC, Mayo K, Sleegers K, Bettens K, Engelborghs S, De Deyn PP, Van BC, Livingston G, Bass NJ, Gurling H, McQuillin A, Gwilliam R, Deloukas P, Al-Chalabi A, Shaw CE, Tsolaki M, Singleton AB, Guerreiro R, Muhleisen TW, Nothen MM, Moebus S, Jockel KH, Klopp N, Wichmann HE, Pankratz VS, Sando SB, Aasly JO, Barcikowska M, Wszolek ZK, Dickson DW, Graff-Radford NR, Petersen RC, van Duijn CM, Breteler MM, Ikram MA, Destefano AL, Fitzpatrick AL, Lopez O, Launer LJ, Seshadri S, Berr C, Campion D, Epelbaum J, Dartigues JF, Tzourio C, Alperovitch A, Lathrop M, Feulner TM, Friedrich P, Riehle C, Krawczak M, Schreiber S, Mayhaus M, Nicolhaus S, Wagenpfeil S, Steinberg S, Stefansson H, Stefansson K, Snaedal J, Bjornsson S, Jonsson PV, Chouraki V, Genier-Boley B, Hiltunen M, Soininen H, Combarros O, Zelenika D, Delepine M, Bullido MJ, Pasquier F, Mateo I, Frank-Garcia A, Porcellini E, Hanon O, Coto E, Alvarez V, Bosco P, Siciliano G, Mancuso M, Panza F, Solfrizzi V, Nacmias B, Sorbi S, Bossu P, Piccardi P, Arosio B, Annoni G, Seripa D, Pilotto A, Scarpini E, Galimberti D, Brice A, Hannequin D, Licastro F, Jones L, Holmans PA, Jonsson T, Riemenschneider M, Morgan K, Younkin SG, Owen MJ, O’Donovan M, Amouyel P, Williams J. Common variants at ABCA7, MS4A6A/MS4A4E, EPHA1, CD33 and CD2AP are associated with Alzheimer's disease. Nat Genet. 2011; 43:429-435. [PubMed: 21460840] 
5. Corder EH, Saunders AM, Strittmatter WJ, Schmechel DE, Gaskell PC, Small GW, Roses AD. Gene dose of apolipoprotein E type 4 allele and the risk of Alzheimer's disease in late onset families. Science. 1993; 261:921-923. [PubMed: 8346443]

6. Corder EH, Saunders AM, Risch NJ, Strittmatter WJ, Schmechel DE, Gaskell PC Jr, Rimmler JB, Locke PA, Conneally PM, Schmader KE, et al. Protective effect of apolipoprotein E type 2 allele for late onset Alzheimer disease. Nat Genet. 1994; 7:180-184. [PubMed: 7920638]

7. Silverman JM, Schnaider-Beeri M, Grossman HT, Schmeidler J, Wang JY, Lally RC. A phenotype for genetic studies of successful cognitive aging. Am J Med Genet B Neuropsychiatr Genet. 2008; 147B:167-173. [PubMed: 18023042]

8. Payton A. The impact of genetic research on our understanding of normal cognitive ageing: 1995 to 2009. Neuropsychol Rev. 2009; 19:451-477. [PubMed: 19768548]

9. Giubilei F, Medda E, Fagnani C, Bianchi V, De Carolis A, Salvetti M, Sepe-Monti M, Stazi MA. Heritability of neurocognitive functioning in the elderly: Evidence from an Italian twin study. Age Ageing. 2008; 37:640-646. [PubMed: 18641001]

10. Swan GE, Carmelli D. Evidence for genetic mediation of executive control: A study of aging male twins. J Gerontol B Psychol Sci Soc Sci. 2002; 57:133-143.

11. Bouchard TJ Jr, McGue M. Genetic and environmental influences on human psychological differences. J Neurobiol. 2003; 54:4-45. [PubMed: 12486697]

12. McClearn GE, Johansson B, Berg S, Perdersen NL, Ahern F, Petrill SA, Plomin R. Substantial genetic influence on cognitive abilities in twins 80 or more years old. Science. 1997; 276:15601563. [PubMed: 9171059]

13. McGue M, Christensen K. The heritability of cognitive functioning in very old adults: Evidence from Danish twins aged 75 years and older. Psychol Aging. 2001; 16:272-280. [PubMed: 11405315]

14. Payami H, Montee K, Kaye J. Evidence for familial factors that protect against dementia and outweigh the effect of increasing age. Am J Hum Genet. 1994; 54:650-657. [PubMed: 8128962]

15. Silverman JM, Smith CJ, Marin DB, Birstein S, Mare M, Mohs RC, Davis KL. Identifying families with likely genetic protective factors against Alzheimer disease. Am J Hum Genet. 1999; 64:832-838. [PubMed: 10053018]

16. Butcher LM, Kennedy JK, Plomin R. Generalist genes and cognitive neuroscience. Curr Opin Neurobiol. 2006; 16:145-151. [PubMed: 16563732]

17. Lee JH, Flaquer A, Stern Y, Tycko B, Mayeux R. Genetic influences on memory performance in familial Alzheimer disease. Neurology. 2004; 62:414-421. [PubMed: 14872023]

18. Swan GE, Reed T, Jack LM, Miller BL, Markee T, Wolf PA, DeCarli C, Carmelli D. Differential genetic influence for components of memory in aging adult twins. Arch Neurol. 1999; 56:11271132. [PubMed: 10488814]

19. Papassotiropoulos A, Stephan DA, Huentelman MJ, Hoerndli FJ, Craig DW, Pearson JV, Huynh KD, Brunner F, Corneveaux J, Osborne D, Wollmer MA, Aerni A, Coluccia D, Hanggi J, Mondadori CR, Buchmann A, Reiman EM, Caselli RJ, Henke K, de Quervain DJ. Common Kibra alleles are associated with human memory performance. Science. 2006; 314:475-478. [PubMed: 17053149]

20. Almeida OP, Schwab SG, Lautenschlager NT, Morar B, Greenop KR, Flicker L, Wildenauer D. KIBRA genetic polymorphism influences episodic memory in later life, but does not increase the risk of mild cognitive impairment. J Cell Mol Med. 2008; 12:1672-1676. [PubMed: 18194457]

21. Nacmias B, Bessi V, Bagnoli S, Tedde A, Cellini E, Piccini C, Sorbi S, Bracco L. KIBRA gene variants are associated with episodic memory performance in subjective memory complaints. Neurosci Lett. 2008; 436:145-147. [PubMed: 18378080]

22. Schaper K, Kolsch H, Popp J, Wagner M, Jessen F. KIBRA gene variants are associated with episodic memory in healthy elderly. Neurobiol Aging. 2008; 29:1123-1125. [PubMed: 17353070]

23. Sanders AE, Wang C, Katz M, Derby CA, Barzilai N, Ozelius L, Lipton RB. Association of a functional polymorphism in the cholesteryl ester transfer protein (CETP) gene with memory decline and incidence of dementia. JAMA. 2010; 303:150-158. [PubMed: 20068209]

24. Mathews CA, Reus VI, Bejarano J, Escamilla MA, Fournier E, Herrera LD, Lowe TL, McInnes LA, Molina J, Ophoff RA, Raventos H, Sandkuijl LA, Service SK, Spesny M, Leon PE, Freimer 
NB. Genetic studies of neuropsychiatric disorders in CostaRica: A model for the use of isolated populations. Psychiatr Genet. 2004; 14:13-23. [PubMed: 15091311]

25. Segura-Wang M, Raventos H, Escamilla M, Barrantes R. Assessment of genetic ancestry and population sub-structure in Costa Rica by analysis of individuals with a familial history of mental disorder. Ann Hum Genet. 2010; 74:516-524. [PubMed: 20946256]

26. Rosero-Bixby L. Socioeconomic development, health interventions and mortality decline in Costa Rica. Scand J Social Med Suppl. 1991; 6:33-42.

27. Biesanz, MH.; Biesanz, KZ.; Biesanz, R. The Ticos: Culture and social change in Costa Rica. Boulder, CO: Lynne Rienner Publishers; 1999.

28. Hughes CP, Berg L, Danzier WL, Coben LA, Martin RL. A new clinical rating scale for staging of dementia. Br J Psychiatry. 1982; 140:566-572. [PubMed: 7104545]

29. Folstein MF, Folstein SE, McHugh PR. "Mini Mental State: A practical method for grading the cognitive state of patients for the clinician. J Psychiatr Res. 1975; 12:189-198. [PubMed: 1202204]

30. Carrion-Baralt JR, Melendez-Cabrero J, Schnaider BM, Sano M, Silverman JM. The Neuropsychological Performance of Nondemented Puerto Rican Nonagenarians. Dement Geriatr Cogn Disord. 2009; 27:353-360. [PubMed: 19293568]

31. Silverman JM, Beeri MS, Schmeidler J, Rosendorff C, Angelo G, Mavris RS, Grossman HT, Elder GA, Carrion-Baralt J, West R. C-reactive protein and memory function suggest antagonistic pleiotropy in very old nondemented subjects. Age Ageing. 2009; 38:237-241. [PubMed: 19147740]

32. West R, Beeri MS, Schmeidler J, Hannigan C, Angelo G, Rosendorff C, Silverman JM. Better memory functioning associated with higher total and LDL cholesterol levels in very elderly subjects without the APOE4 allele. Am J Geriatr Psychiatry. 2008; 16:781-785. [PubMed: 18757771]

33. Holtzer R, Verghese J, Xue X, Lipton RB. Cognitive processes related to gait velocity: Results from the Einstein Aging Study. Neuropsychology. 2006; 20:215-223. [PubMed: 16594782]

34. Siedlecki KL, Honig LS, Stern Y. Exploring the structure of a neuropsychological battery across healthy elders and those with questionable dementia and Alzheimer's disease. Neuropsychology. 2008; 22:400-411. [PubMed: 18444718]

35. Welsh KA, Butters N, Mohs RC, Beekly D, Edland S, Fillenbaum G, Heyman A. The Consortium to Establish a Registry for Alzheimer's Disease (CERAD). Part V. A normative study of the neuropsychological battery. Neurology. 1994; 44:609-614. [PubMed: 8164812]

36. Wechsler, D. Wechsler Memory Scale-III. San Antonio, TX: The Psychological Corporation; 1997.

37. Reitan, RM.; Wolfson, D. The Halstead-Reitan Neuropsychological Test Battery: Theory and clinical inter-pretation. S. Tucson AZ: Neuropsychology Press; 1993.

38. Wechsler, D. Wechsler Adult Intelligence Scale — Revised administration and scoring manual. New York: Psychological Corporation; 1981.

39. Benton, AL.; Hamsher, K. Multilingual aphasia examination. Iowa City: University of Iowa Press; 1978.

40. Newcombe, F. Missile wounds of the brain. London: Oxford University Press; 1969.

41. Byrd DA, Touradji P, Tang MX, Manly JJ. Cancellation test performance in African American, Hispanic, and White elderly. J Int Neuropsychol Soc. 2004; 10:401-411. [PubMed: 15147598]

42. Almasy L, Blangero J. Multipoint quantitative-trait linkage analysis in general pedigrees. Am J Hum Genet. 1998; 62:1198-1211. [PubMed: 9545414]

43. Amos CI, Zhu DK, Boerwinkle E. Assessing genetic linkage and association with robust components of variance approaches. Ann Hum Genet. 1996; 60:143-160. [PubMed: 8839128]

44. Allison DB, Neale MC, Zannolli R, Schork NJ, Amos CI, Blangero J. Testing the robustness of the likelihood-ratio test in a variance-component quantitative-trait loci-mapping procedure. Am J Hum Genet. 1999; 65:531-544. [PubMed: 10417295]

45. Hopper JL, Mathews JD. Extensions to Multivariate Normal-Models for Pedigree Analysis. Ann Hum Genet. 1982; 46:373-383. [PubMed: 6961886] 
46. Almasy L, Dyer TD, Blangero J. Bivariate quantitative trait linkage analysis: Pleiotropy versus coincident linkages. Genet Epidemiol. 1997; 14:953-958. [PubMed: 9433606]

47. Christensen $\mathrm{H}$. What cognitive changes can be expected with normal ageing? Aust N Z J Psychiatry. 2001; 35:768-775. [PubMed: 11990887]

48. Greenwood PM, Parasuraman R. Normal genetic variation, cognition, and aging. Behav Cogn Neurosci Rev. 2003; 2:278-306. [PubMed: 15006290]

49. Wisdom NM, Callahan JL, Hawkins KA. The effects of apolipoprotein E on non-impaired cognitive functioning: A meta-analysis. Neurobiol Aging. 2009; 32:63-74. [PubMed: 19285755]

50. Goldman WP, Morris JC. Evidence that age-associated memory impairment is not a normal variant of aging. Alzheimer Dis Assoc Disord. 2001; 15:72-79. [PubMed: 11403335]

51. Savitz J, Solms M, Ramesar R. Apolipoprotein E variants and cognition in healthy individuals: A critical opinion. Brain Res Rev. 2006; 51:125-135. [PubMed: 16378640]

52. Stern Y. The concept of cognitive reserve: A catalyst for research. J Clin Exp Neuropsychol. 2003; 25:589-593. [PubMed: 12815497]

53. Snowdon DA. Healthy aging and dementia: Findings from the Nun Study. Ann Intern Med. 2003; 139:450-454. [PubMed: 12965975]

54. Snowdon DA. Aging and Alzheimer's disease: Lessons from the Nun Study. Gerontologist. 1997; 37:150-156. [PubMed: 9127971]

55. Berlau DJ, Corrada MM, Head E, Kawas CH. APOE epsilon2 is associated with intact cognition but increased Alzheimer pathology in the oldest old. Neurology. 2009; 72:829-834. [PubMed: 19255410]

56. Salthouse TA. Memory aging from 18 to 80. Alzheimer Dis Assoc Disord. 2003; 17:162-167. [PubMed: 14512830] 


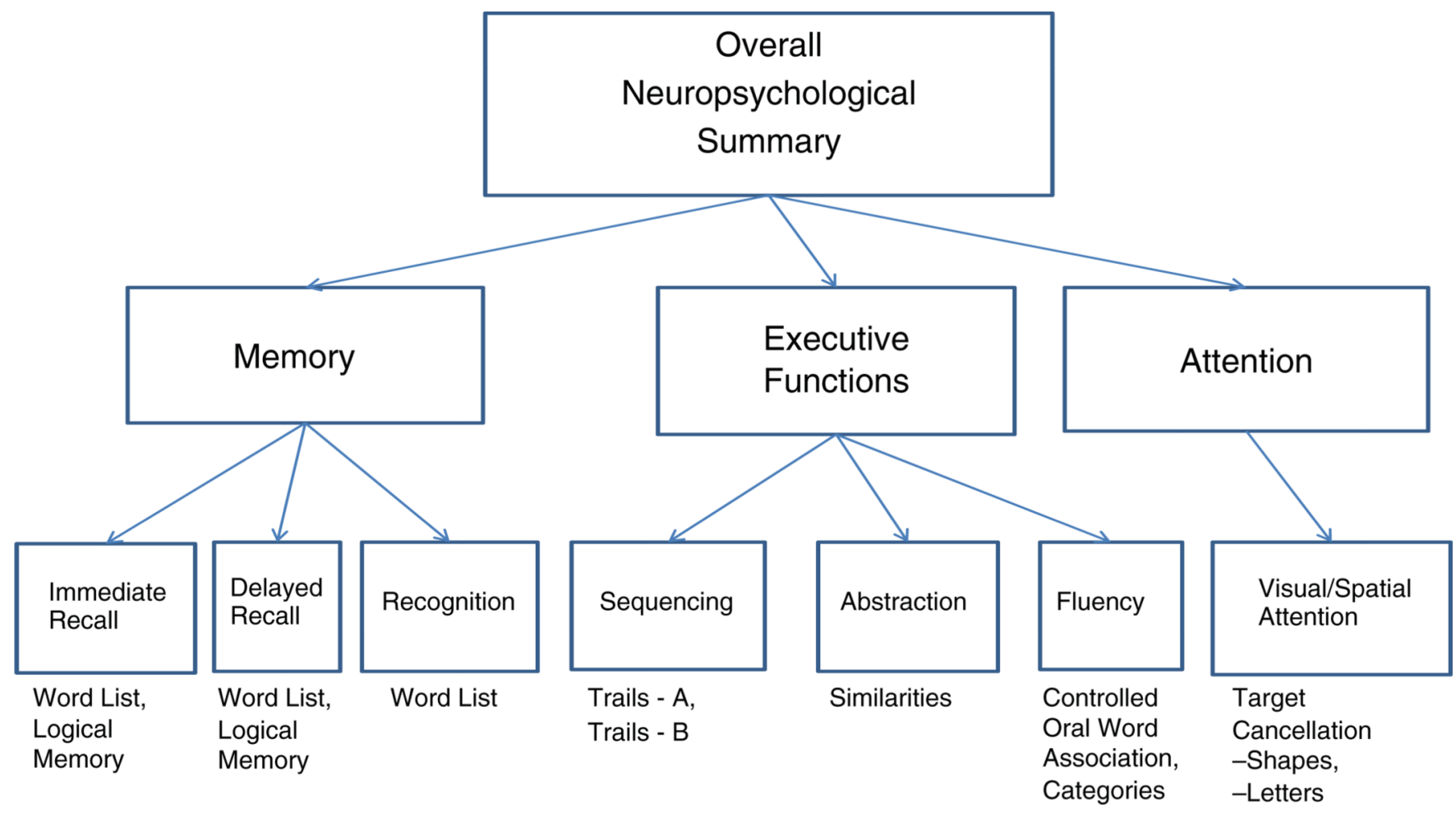

Fig. 1.

Three levels of neuropsychological phenotypes examined and the specific tests used. Note: Two versions of the target cancellation test (shapes and letters) were used to establish the attention domain score, middle level. However, these two tests were deemed insufficiently distinct to be treated separately, i.e., as individual neuropsychological functions at the bottom level. 


\section{Table 1}

The demographic, neuropsychological phenotype characteristics of SCA probands and their offspring

\begin{tabular}{|c|c|c|c|}
\hline Characteristic & SCA probands & $\begin{array}{l}\text { Offspring of } \\
\text { SCA probands }\end{array}$ & Total \\
\hline \multicolumn{4}{|l|}{ Demographics } \\
\hline$N$ & 65 & 188 & 253 \\
\hline Age y (SD) & $93.4(3.0)$ & $66.4(5.0)$ & $73.3(12.7)$ \\
\hline Female n $(\%)$ & $43(66)$ & $122(65)$ & $156(65)$ \\
\hline Education y (SD) & $3.6(2.9)$ & $8.6(5.1)$ & $7.3(5.1)$ \\
\hline \multicolumn{4}{|l|}{ Cognitive phenotypes } \\
\hline & Mean (SD) & Mean (SD) & Mean (SD) \\
\hline Neuropsychological summary ${ }^{*}$ & $-0.20(2.52)$ & $0.09(2.30)$ & $0.00(2.37)$ \\
\hline Memory $^{*}$ & $-0.16(2.66)$ & $0.03(2.54)$ & $-0.04(2.59)$ \\
\hline Immediate Recall $^{*}$ & $-0.16(1.74)$ & $0.05(1.71)$ & $-0.02(1.73)$ \\
\hline Delayed Recall $^{*}$ & $-0.09(1.76)$ & $0.02(1.75)$ & $-0.01(1.75)$ \\
\hline Recognition (Word list recognition) ${ }^{\dagger}$ & $15.2(3.6)$ & $18.1(2.1)$ & $17.3(2.87)$ \\
\hline Executive functions $*$ & $-0.22(2.14)$ & $0.07(2.37)$ & $-0.02(2.32)$ \\
\hline Sequencing $*$ & $-0.19(1.52)$ & $0.01(1.74)$ & $-0.04(1.70)$ \\
\hline Fluency $^{*}$ & $-0.16(1.67)$ & $0.07(1.81)$ & $0.00(1.78)$ \\
\hline Abstraction (Similarities) ${ }^{\dagger}$ & $7.9(5.2)$ & $14.1(6.1)$ & $12.4(6.5)$ \\
\hline Attention ${ }^{*}$ & $-0.42(1.00)$ & $0.05(0.95)$ & $0.02(0.96)$ \\
\hline
\end{tabular}




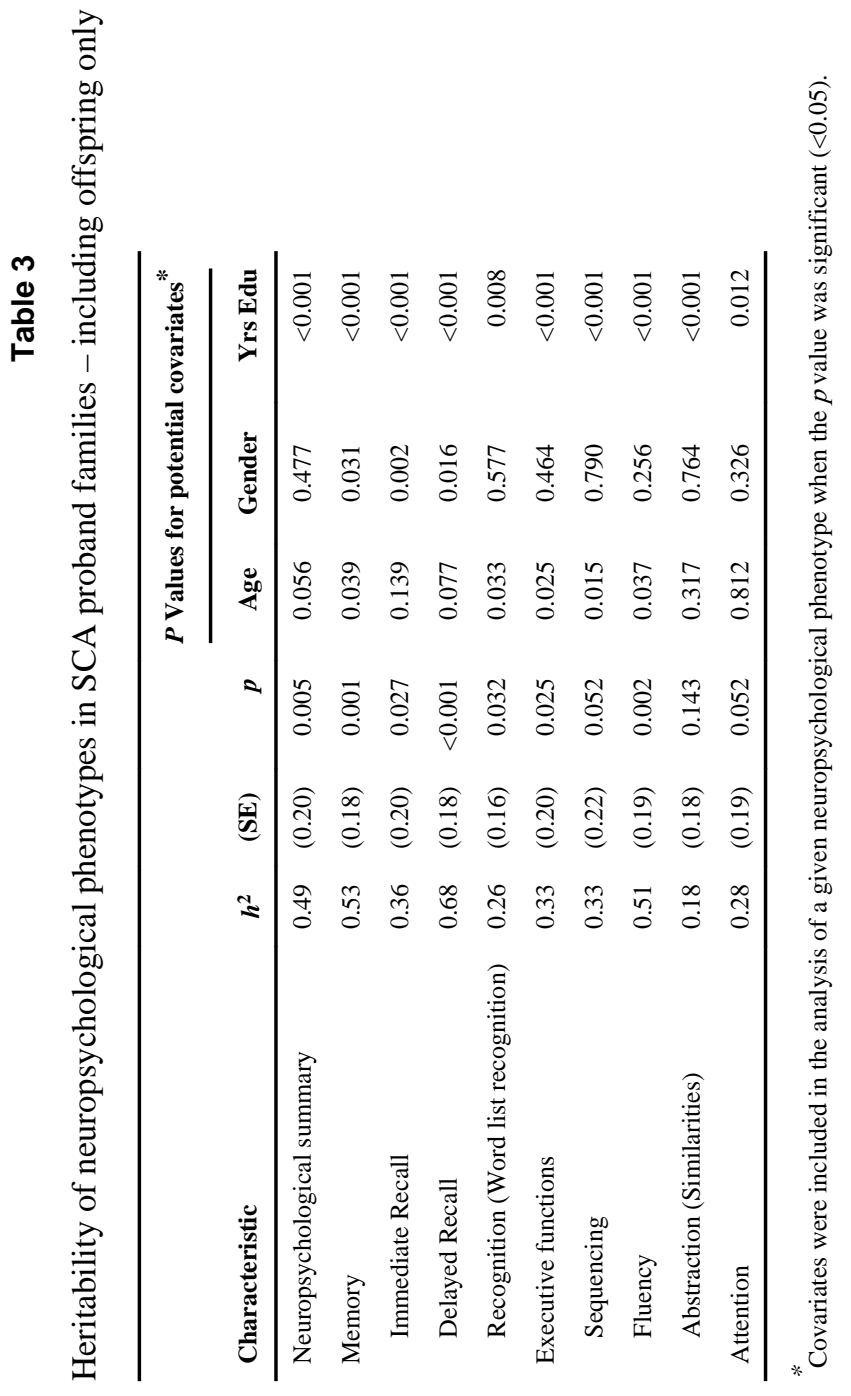




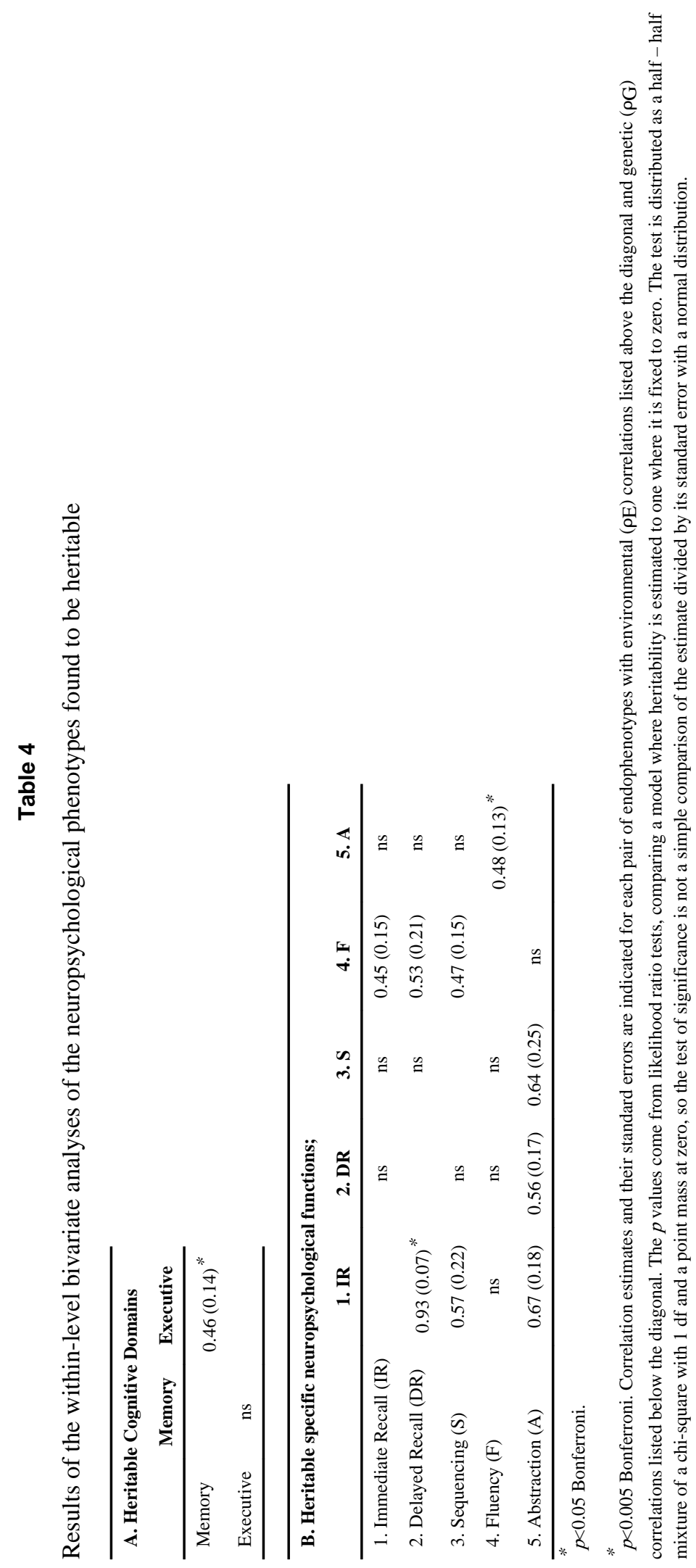

